\title{
LUT
}

Lappeenranta

University of Technology

\section{Solid-liquid separation of hydrolysates obtained from enzymatic hydrolysis of cardboard waste}

Kinnarinen Teemu, Huhtanen Mikko, Häkkinen Antti, Louhi-Kultanen Marjatta

This is a Final draft version of a publication

published by Elsevier

in Industrial Crops and Products

DOI: $\quad 10.1016 /$ j.indcrop.2012.01.010

Copyright of the original publication: (c) Elsevier 2012

Please cite the publication as follows:

Kinnarinen, T., Huhtanen, M., Häkkinen, A., Louhi-Kultanen, M., Solid-liquid separation of hydrolysates obtained from enzymatic hydrolysis of cardboard waste, Industrial Crops and Products, 2012, 38(1): 72-80. DOI: 10.1016/j.indcrop.2012.01.010 


\title{
Solid-liquid separation of hydrolysates obtained from enzymatic hydrolysis of cardboard waste
}

\author{
Teemu Kinnarinen*, Mikko Huhtanen, Antti Häkkinen, Marjatta Louhi-Kultanen \\ LUT Chemistry, Lappeenranta University of Technology, \\ P.O. Box 20, FIN-53851 Lappeenranta, Finland \\ *Corresponding author tel: +358 40562 1398, e-mail: teemu.kinnarinen@lut.fi
}

\begin{abstract}
Enzymatic hydrolysis provides an environmentally friendly pathway from cellulosic biomass to sugars that can be fermented to produce ethanol. The hydrolysis step has a marked influence on the overall efficiency of the bioethanol process. Since the cellulosic substrate cannot be completely cleaved to sugars, there always remains a solid residue suspended in the hydrolysate. Solid-liquid separation performed at this stage can improve subsequent membrane filtration (for recycling the enzymes, or concentrating the sugars prior to fermentation, for example). The fermentation process can also be controlled more readily if the cellulosic residue is removed after the hydrolysis. For the present study, shredded cardboard was chosen as the cellulosic raw material. Non-degraded solids were separated from enzymatically produced hydrolysates using a laboratory-scale pressure filter. The influence of process-related variables, such as enzyme dosage, the level of pre-milling, and the initial substrate concentration were investigated by determining the concentrations of glucose and xylose during the hydrolysis. Filtration tests were carried out at three different pressures immediately after each batch of hydrolysis was completed. The results show that some of the chosen variables have an unexpected effect on the filtration characteristics. The degree of conversion of the cellulosic substrate to glucose and xylose was also affected by the investigated process variables.
\end{abstract}

Keywords: Enzymatic hydrolysis, Cardboard waste, Pressure filtration, Cake resistance, Compressibility index

\section{Introduction}

Bioethanol produced from lignocellulosic raw materials has the potential to be one of the most important solutions for reducing the dependence upon fossil fuels in the near future. In spite of numerous technical challenges, industrial-scale production of bioethanol from lignocellulosic biomasses is becoming an option worth consideration. Cellulose is a linear biopolymer consisting of glucose units linked to each other by $\beta-(1-4)$ linkages (Krässing, 1993; Balat et $a l ., 2008)$. Other significant components of cellulosic biomasses include hemicelluloses and lignin (Balat et al., 2008). Extractives (for example tar and resin), proteins, organic acids and pectins (Blasi et al., 1999; Sluiter et al., 2010) are present in smaller amounts. Cellulose, hemicellulose and lignin contents of typical biomasses are 40-60, 20-40, and 10-25 w-\%, respectively (Lin et al., 2010). The main reason for the attempts to use lignocellulosic biomasses to replace fossil fuels is that they are found very abundantly in nature: lignocellulose represents approximately $90 \%$ of the plant biomass on earth (Lin and Tanaka, 2006). In addition to their abundance and renewability, cellulosic materials are interesting as fuel replacements, because bioethanol can be used in existing gasoline motors (Wingren et al., 2008).

Enzymatic hydrolysis is an environmentally benign process step that can be used for cleaving the cellulose polymers to glucose, because currently available microorganisms cannot 
effectively convert cellulose directly to ethanol. The recalcitrance of cellulosic materials to enzymatic hydrolysis is generally regarded as the most significant obstacle to the viable conversion of cellulose to ethanol. A large variety of pretreatment methods, including, for example, steam explosion, ammonia fiber explosion and treatment with pressurized hot water at $150-200{ }^{\circ} \mathrm{C}$, have been developed to improve the efficiency of hydrolysis (Virkajärvi et al., 2009; Kumar et al., 2009). Ease of saccharification depends on the structure of the raw material. Since cardboard and paper have already been pulped at least once, pretreatment of such feedstocks prior to hydrolysis is not necessary, and could result in improved yields (Yáñez et al., 2004).

In this experimental study, the solid-liquid separation characteristics of hydrolysates produced by enzymatic hydrolysis from cardboard waste are discussed. It is important to know the filtration behavior of the solid residue that remains after converting a large proportion of the polymeric raw material to monomeric sugars. Significant changes in the properties of the solid take place as the enzymatic hydrolysis proceeds, for example reduction of the fiber dimensions (Clarke et al., 2011), an increase in the crystallinity of cellulose (Mansfield et al., 1999) and an increase in the proportion of lignin in the solid fraction. The residual solids, if not removed after the hydrolysis, can detrimentally affect the downstream processes, such as fermentation and product separation (Burke et al., 2011). The filter cake formed from the solid residue can be very compressible, which makes the separation more difficult. Consequently, larger filtration areas and a longer filtration times are required, which increase the separation costs. Scale-up of the filtration process is also made more complicated because of the high compressibility of the filter cakes. Taking into consideration that all separation operations together can account for more than half of the capital and operating cost of a bioethanol process (Kochergin and Miller, 2011), too little effort has been made to thoroughly understand the influence of hydrolysis conditions on the solid-liquid separation processes.

\section{Materials and methods}

\subsection{Raw material and preliminary analyses}

The raw material used in the experiments was air dry cellulosic waste consisting mainly of shredded cardboard. Besides cellulose, hemicelluloses and lignin, pieces of plastic, metals, as well as inorganic minerals were found in the raw material. The cellulose content of the raw material was $63 \mathrm{w}-\%$, determined according to the method of Black (1951). Compared to the air dry material at $20{ }^{\circ} \mathrm{C}$, the moisture content was $6.3 \mathrm{w}-\%$, after drying to constant weight at $100{ }^{\circ} \mathrm{C}$. The proportion of lignin was $11.5 \mathrm{w}-\%$, measured using a liquid chromatographic method with the following specifications: HP Agilent 1050 device with Phenomenex Luna $3 \mathrm{u}$ $\mathrm{C} 18(2) 100 \times 2.0 \mathrm{~mm}$ column, $20 \mathrm{mM}$ ammonium hydroxide (50 v-\%) and methanol (50 v-\%) as eluents, $\mathrm{pH} 9$, injection volume $5 \mu \mathrm{L}$, detection by UV/VIS at $254 \mathrm{~nm}$ and electrospray ionization / mass spectrometer (ESI-MS). The hemicellulose content was not measured in this study, but it was estimated to be about $14 \mathrm{w}-\%$, assuming that no extractives were present. Because of the presence of inorganic matter, such as calcium carbonate that is used as a filler in paper and paperboard, the ash content was quite high, $11.1 \mathrm{w}-\%$. The ash content was determined according to ISO 1762:2001 standard.

The cellulosic raw material was divided into two classes; 1 ) original untreated cardboard waste and 2) milled cardboard waste. Milling was carried out by using a specially designed machine owned by the University of Oulu. The maximum size of the particles exiting the machine was $1.5 \mathrm{~mm}$. As a result of milling, the particle shape was also changed from a more-or-less crooked 
flake to quite spherical. Five sieves (125 to $1400 \mu \mathrm{m}$ ) were then utilized for dividing the milled material into six size fractions, the proportions of which are shown in Fig. 1.

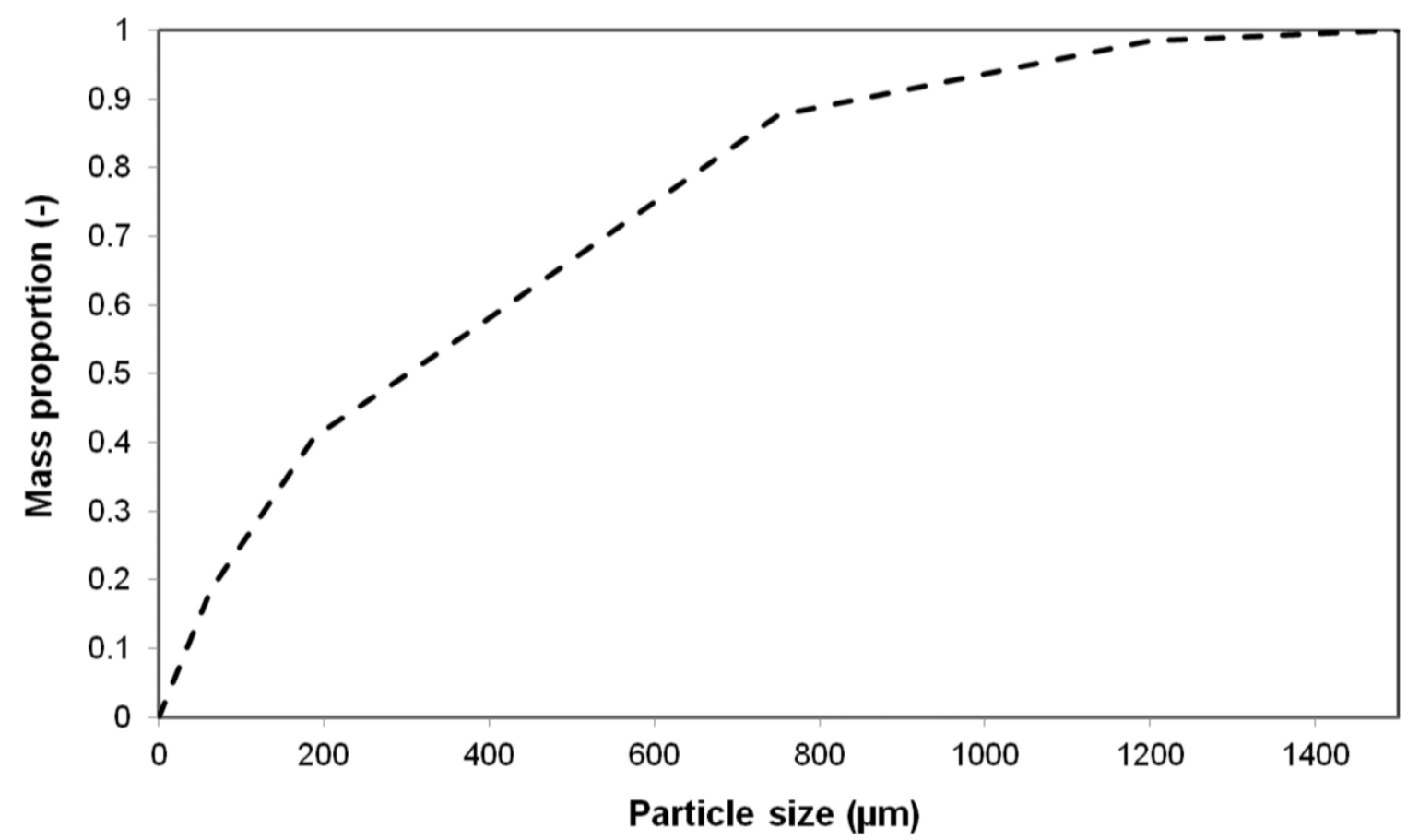

Fig. 1. Approximate particle size distribution of the milled raw material.

The ash content (Table 1) in the milled raw material and in two of the classified size fractions $(<125 \mu \mathrm{m}$ and 1000-1400 $\mu \mathrm{m})$ were determined according to ISO 1762:2001 standard. Most experiments were performed using the non-milled raw material, referred to as "original" in this paper. The original size of the pieces was about $10 \times 20 \times 5 \mathrm{~mm}$, but it is difficult to accurately describe the particle size or shape of such a heterogeneous material. The effect of the material heterogeneity on the experiments was minimized by mixing the cardboard waste manually and by taking several sub-samples from different locations. The sub-samples were then combined, mixed again and weighed for the hydrolysis experiments.

Table 1 Ash content of the milled raw material as the average of two determinations: All fractions $(0-1.5 \mathrm{~mm})$, the coarsest fraction $(1-1.4 \mathrm{~mm})$ and the finest fraction $(<$ $0.125 \mathrm{~mm}$ ).

\begin{tabular}{cccc}
\hline $\begin{array}{c}\text { Particle size } \\
{[\mathrm{mm}]}\end{array}$ & $\begin{array}{c}\text { Ash content } \\
{[\mathbf{w}-\%]}\end{array}$ & $\begin{array}{c}\text { Average ash content } \\
{[\mathbf{w}-\%]}\end{array}$ & $\begin{array}{c}\text { Relative ash } \\
\text { content [w-\%] }\end{array}$ \\
\hline \multirow{2}{*}{$1-1.4$} & 10.09 & 10.0 & 89.4 \\
& 9.81 & & \\
$0-1.5$ & 11.05 & 11.1 & 100 \\
& 11.22 & & 129.4 \\
\hline 0.125 & 14.19 & 14.4 & \\
\hline
\end{tabular}




\subsection{Experimental plan}

The total number of hydrolysis batches produced was 14 . The experimental variables included 1) enzyme dosage, 2) particle size of the raw material, and 3) initial solid concentration of the suspension. A laboratory scale, Nutsche type, pressure filter was used for studying the influence of the variables on the filterability of the hydrolysates. Because of the filter design, in particular the small diameter of the feed pipe, the maximum solid concentration used in this study was restricted to $10 \%$. The experimental plan is presented in Table 2 .

Table 2 The experimental plan.

\begin{tabular}{|c|c|c|c|c|c|}
\hline \multirow{2}{*}{$\begin{array}{l}\text { Experimen } \\
t\end{array}$} & \multicolumn{3}{|c|}{ Enzyme dosage } & \multirow{2}{*}{$\begin{array}{c}\text { Solid concentration } \\
{[\mathrm{w}-\%]}\end{array}$} & \multirow{2}{*}{$\begin{array}{c}\text { Particle sizt } \\
{[\mu \mathrm{m}]}\end{array}$} \\
\hline & $\begin{array}{c}\mathrm{C}-\mathrm{Tec} \\
{[\mathrm{mL} / \mathrm{kg} \text { cellulose }]} \\
\end{array}$ & $\begin{array}{c}\text { C-Tec } \\
\text { [FPU/g cellulose] }\end{array}$ & $\begin{array}{c}\text { H-Tec } \\
\text { [mL/kg substrate] }\end{array}$ & & \\
\hline 1 & 320 & 38.4 & 64 & 10 & original \\
\hline 2 & 140 & 16.8 & 28 & 10 & original \\
\hline 3 & 140 & 16.8 & 28 & 10 & $0-125$ \\
\hline 4 & 140 & 16.8 & 28 & 10 & $125-250$ \\
\hline 5 & 140 & 16.8 & 28 & 10 & $250-500$ \\
\hline 6 & 140 & 16.8 & 28 & 10 & $500-1000$ \\
\hline 7 & 140 & 16.8 & 28 & 10 & $1000-1400$ \\
\hline 8 & 140 & 16.8 & 28 & 10 & $0-1400$ \\
\hline 9 & 140 & 16.8 & 28 & 5 & original \\
\hline 10 & 140 & 16.8 & 28 & 7.5 & original \\
\hline 11 & 140 & 16.8 & 28 & 10 & original \\
\hline 12 & 320 & 38.4 & 8 & 10 & original \\
\hline 13 & 40 & 4.8 & 64 & 10 & original \\
\hline 14 & 40 & 4.8 & 8 & 10 & original \\
\hline
\end{tabular}

\subsection{Experimental procedure}

A jacketed glass reactor with a volume of $3 \mathrm{dm}^{3}$ was used as the hydrolysis tank. The reactor temperature was controlled by a Lauda RK8 KP thermostat, capable of both heating and cooling. The solid-liquid suspensions were prepared from cold tap water and the cellulosic raw material. A sufficient amount of sulfuric acid (J.T. Baker, 95-97 \%, Netherlands) at a concentration of $20 \mathrm{w}-\%$ was added to adjust the $\mathrm{pH}$ to 5.0. The mass of pure $\mathrm{H}_{2} \mathrm{SO}_{4}$ required for the $\mathrm{pH}$ adjustment was approximately $8 \%$ of the mass of the raw material. It is possible that dissolution of $\mathrm{CaCO}_{3}$ (a filler agent in the cardboard) and formation of $\mathrm{CaSO}_{4}$ have occurred as a result of $\mathrm{pH}$ adjustment. Presence of fine $\mathrm{CaSO}_{4}$ may have had an influence on the filtration stage as well. The hydrolysis batch was mixed with a pitched-blade turbine (mixer diameter / tank diameter $=1 / 2$ ) at a constant rate of $200 \mathrm{rpm}$ that corresponded to a tip speed of $0.84 \mathrm{~m} / \mathrm{s}$.

The duration of each hydrolysis was 72 hours. To start the enzymatic hydrolysis, a hemicellulase preparation (Novozymes Cellic HTec) was added into the pH-adjusted suspension at an initial temperature of $40^{\circ} \mathrm{C}$. Immediately after adding the hemicellulases, the 
suspension was heated to $71{ }^{\circ} \mathrm{C}$ and kept at that temperature for 10 minutes in order to improve activation. After cooling down to $46^{\circ} \mathrm{C}$, a cellulase preparation (Novozymes Cellic CTec) was added. Since the activity of this kind of cellulase preparation can be measured in numerous ways and since single activities do not satisfactorily describe the performance of the product, cellulase activities were not measured in this study. According to Alvira et al. (2011), the activity of Cellic CTec is approximately $120 \mathrm{FPU} / \mathrm{mL}$.

The filtration experiments were conducted using a laboratory scale Nutsche pressure filter. Nitrogen was used to pressurize the filter after filling the filter chamber with the hydrolyzed suspension. The filter was kept at the required temperature with a Lauda RK8 KP thermostat, circulating water through the jacket of the filter. The filter medium, of T1000 type, supplied by Pall Corporation (Bad Kreuznach, Germany), was a disc of cellulose with an effective diameter of $49 \mathrm{~mm}$, when held in its sealing. The thickness of the filter medium was approximately 3.6 $\mathrm{mm}$. Assuming that the surface of the filter medium was smooth, the filtration area, therefore, was $18.9 \mathrm{~cm}^{2}$. The cut-off particle size of the cellulosic filter medium was $24 \mu \mathrm{m}$. Thanks to the properties of the filter medium and the filter cake, no suspended particles were observed in the filtrates. For each test, a fresh disc of filter medium was first wetted with water and installed on the bottom grid of the filter. The mass of feed slurry was $200 \mathrm{~g}$ in all experiments. The applied filtration pressures were 1.0, 3.5, and 6.0 bar.

\subsection{Composition of the hydrolysates}

Seven samples were collected from the hydrolysis tank during each test run. The concentrations of glucose and xylose in the produced hydrolysates were determined by high performance liquid chromatography (HPLC, HP Agilent 1100). The column, a Varian Metacarb 87H, was kept at $60{ }^{\circ} \mathrm{C}$ and $0.005 \mathrm{M}$ sulfuric acid was used as the eluent. Each run was performed at least twice. The injection volume was $10 \mu \mathrm{L}$ and a precolumn was connected to the feed line to protect the column from solid particles. Prior to the analyses, the final samples $(1 \mathrm{~mL})$ were prepared by filtering through a syringe filter with a nominal pore size of $0.2 \mu \mathrm{m}$. The concentration of total dissolved solids in each sample of solid-free hydrolysate was determined by drying to constant weight in a heating chamber at $105^{\circ} \mathrm{C}$.

\subsection{Calculations}

The yield of glucose in the enzymatic conversion, $Y$, was calculated as:

$Y=\frac{c_{g l c}}{c_{c e l l}}$

where $c_{g l c}(\mathrm{~g} / \mathrm{L})$ is the glucose concentration measured by HPLC and $c_{c e l l}(\mathrm{~g} / \mathrm{L})$ is the initial cellulose concentration.

The conventional theory of constant pressure filtration was applied for the calculations. For calculating the specific cake resistances and cake compressibility indices, the filtration data were modified by plotting the filtration time per volume of filtrate $(\mathrm{t} / \mathrm{V})$ against the volume of filtrate (V). The slopes of the lines were then used to calculate the specific cake resistances. An example of this graphical presentation is shown in Fig. 2, where the slopes are determined for the experiments performed using different enzyme dosages. 


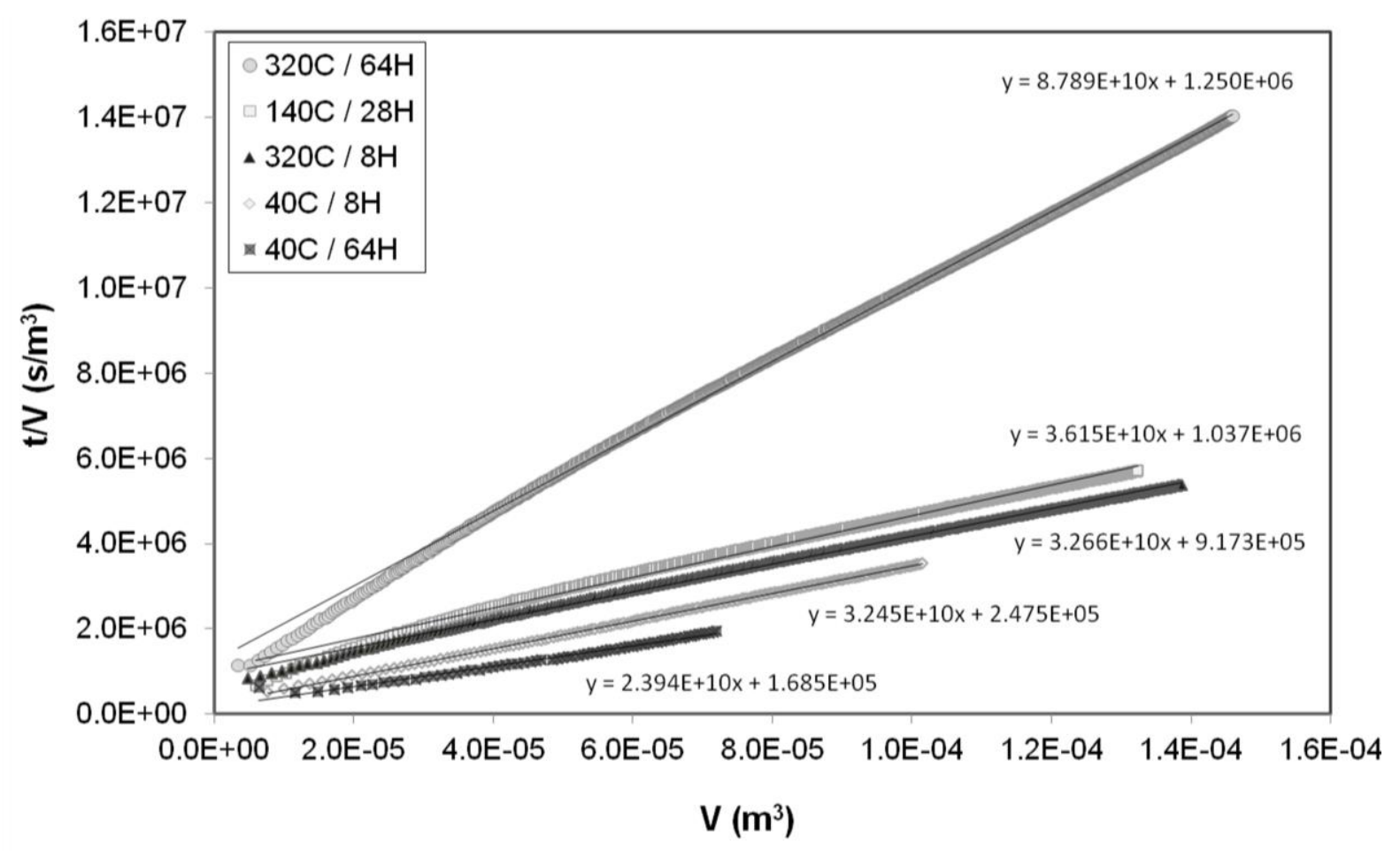

Fig. 2. Determination of slopes for calculating the average resistances of the filter cakes. Case: enzyme dosage as the variable.

Average specific resistances $\alpha_{a v}(\mathrm{~m} / \mathrm{kg})$ of the filter cakes were calculated by Eq. (2):

$\alpha_{a v}=\frac{2 a A^{2} \Delta p}{\mu c}$

where $a\left(\mathrm{~s} / \mathrm{m}^{6}\right)$ is the slope obtained from, for example, Fig. $2, A\left(\mathrm{~m}^{2}\right)$ is the filtration area, $\Delta p$ $(\mathrm{Pa})$ is the applied pressure, $\mu(\mathrm{Pa} \mathrm{s})$ is the dynamic viscosity of the liquid, and $c\left(\mathrm{~kg}_{\text {solids }} / \mathrm{m}^{3}\right.$ filtrate $)$ is the filtration concentration - the mass of solid material in the filter cake per unit volume of filtrate collected.

Resistances $R_{c}(1 / \mathrm{m})$ of the filter cakes were calculated as

$R_{c}=w \alpha_{a v}$

where $w\left(\mathrm{~kg} / \mathrm{m}^{2}\right)$ is the mass of solids deposited per unit area.

Resistances of the filter media $R_{m}(1 / \mathrm{m})$ were estimated using Eq. (4):

$R_{m}=\frac{b A \Delta p}{\mu}$

where $b\left(\mathrm{~s} / \mathrm{m}^{3}\right)$ is the interception point of the line and the y-axis as shown in Fig. 2.

The cake compressibility index, $n$, was determined according to a simple mathematical fit (Eq. 4) presented, for example, by Wakeman and Tarleton (1999).

$\alpha=\alpha_{0} \Delta p^{n}$

where $\alpha_{0}$ is the specific cake resistance at unit applied pressure.

Calculations related to pressure filtration are described in more detail by Svarovsky (1981). 
The average porosity $\varepsilon_{a v}$ of a filter cake was calculated based on dimensions of the cake:

$\varepsilon_{a v}=\frac{V_{\text {pores }}}{V_{\text {cake }}}$

where $V_{\text {pores }}$ is the total volume of pores in the cake with a volume $V_{\text {cake. }}$ The pore volume was obtained by drying the cake to constant weight in a heating chamber. During the drying, water was evaporated and the evaporated volume was calculated based on the loss of weight, using a water density of $1000 \mathrm{~kg} / \mathrm{m}^{3}$. Dissolved solids were omitted in the calculations due to their small influence on the pore volume.

\section{Results and discussion}

\subsection{Conversion of cellulose to glucose}

Different proportions of the original raw material were converted to glucose during the hydrolysis stage. All the variables, including enzyme dosage (ED), particle size of the raw material (PS), and solid concentration (SC) of the suspension, were observed to have an influence on the conversion yield, $Y$, as summarized in Fig. 3. The conversion yields varied from very poor $(14 \%)$ to satisfactory $(55 \%)$.

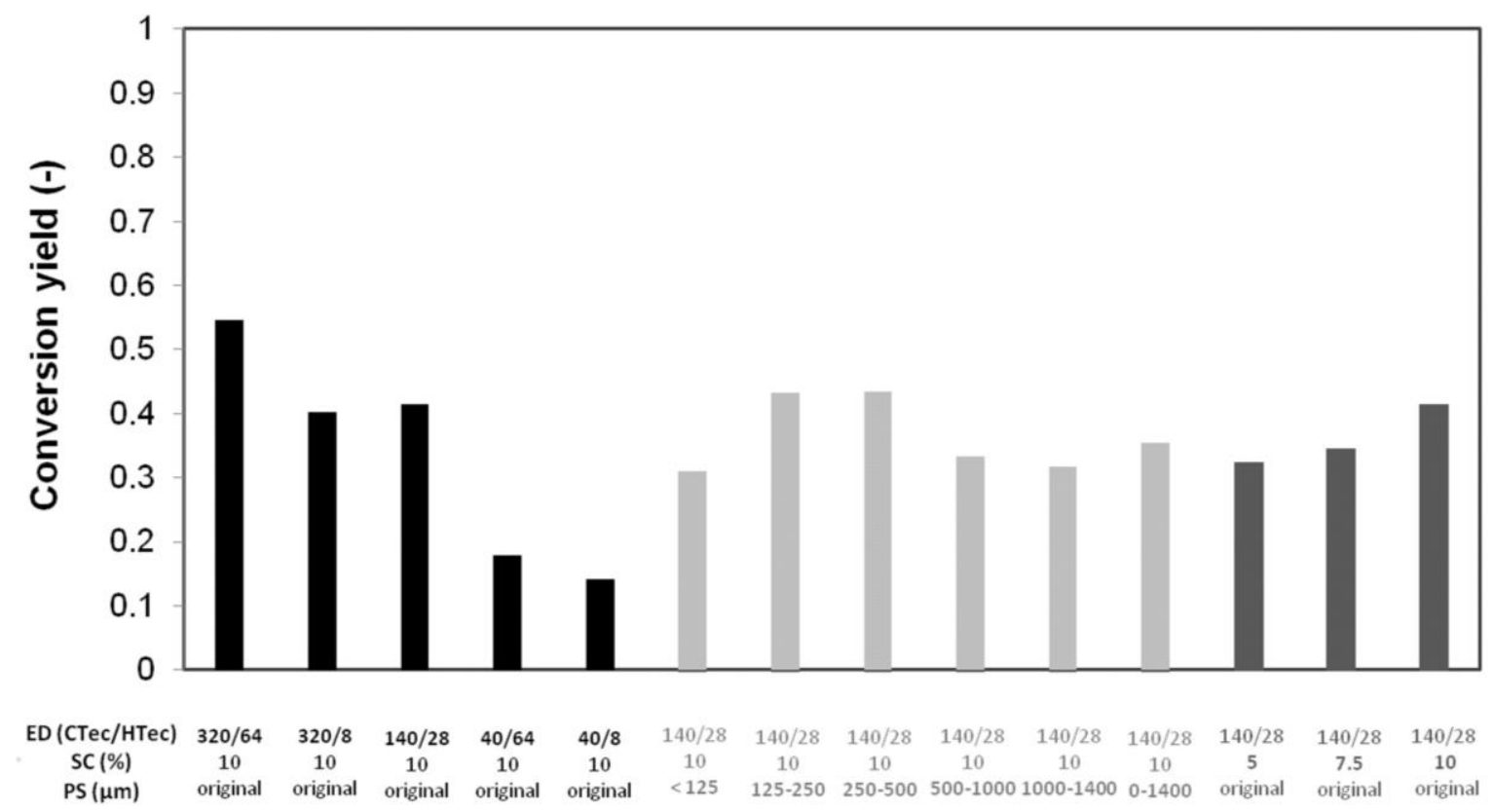

Fig. 3. Final conversion yields of the raw material to glucose at different enzyme dosages, particle sizes, and solid concentrations of the suspension. The unit of ED is $\mathrm{mL}_{\text {hemicellulase }} / \mathrm{kg}_{\text {raw material }}$ for the hemicellulase preparation and $\mathrm{mL}_{\text {cellulase }}$ $\mathrm{kg}_{\text {cellulose }}$ for the cellulase preparation.

Glucose concentrations in the liquid phase of the hydrolyzed suspensions, determined after 1, 3, 6, 15, 24, 48, and 72 hours of enzymatic hydrolysis, are presented in Figs. 4, 5, and 6.

Figure 4 shows the effect of enzyme dosage on glucose concentration in the hydrolysate. Generally, it can be concluded that the more the enzyme is added, the greater the cellulose 
component of the raw material that is converted to glucose. There is a large difference between the glucose concentrations obtained at the highest enzyme dosage $\left(320 \mathrm{~mL}\right.$ cellulase $/ \mathrm{kg}_{\text {cellulose }}$ and $64 \mathrm{~mL}$ hemicellulase $\left./ \mathrm{kg}_{\text {raw material }}\right)$ and the lowest dosage $\left(40 \mathrm{~mL}\right.$ cellulase $/ \mathrm{kg}_{\text {cellulose }}$ and $8 \mathrm{~mL} \mathrm{Lemicellulase}_{\text {he }}$ $/ \mathrm{kg}_{\text {raw material }}$ ). The volume of enzyme spent, per gram of glucose formed is, however, increasing sharply as the conversion yield is improved. An eight-fold increase in the dose of both enzymes was required to increase the final glucose concentration from $10 \mathrm{~g} / \mathrm{L}$ to $38 \mathrm{~g} / \mathrm{L}$.

The concentrations of dissolved solids in the filtrates ranged from 1.9 to $5.3 \mathrm{w}-\%$. On average, the combined mass proportion of glucose and xylose in the dissolved solids was $81 \%$. The proportion of glucose and xylose was highest (93\%) at the highest conversion yield (0.55).

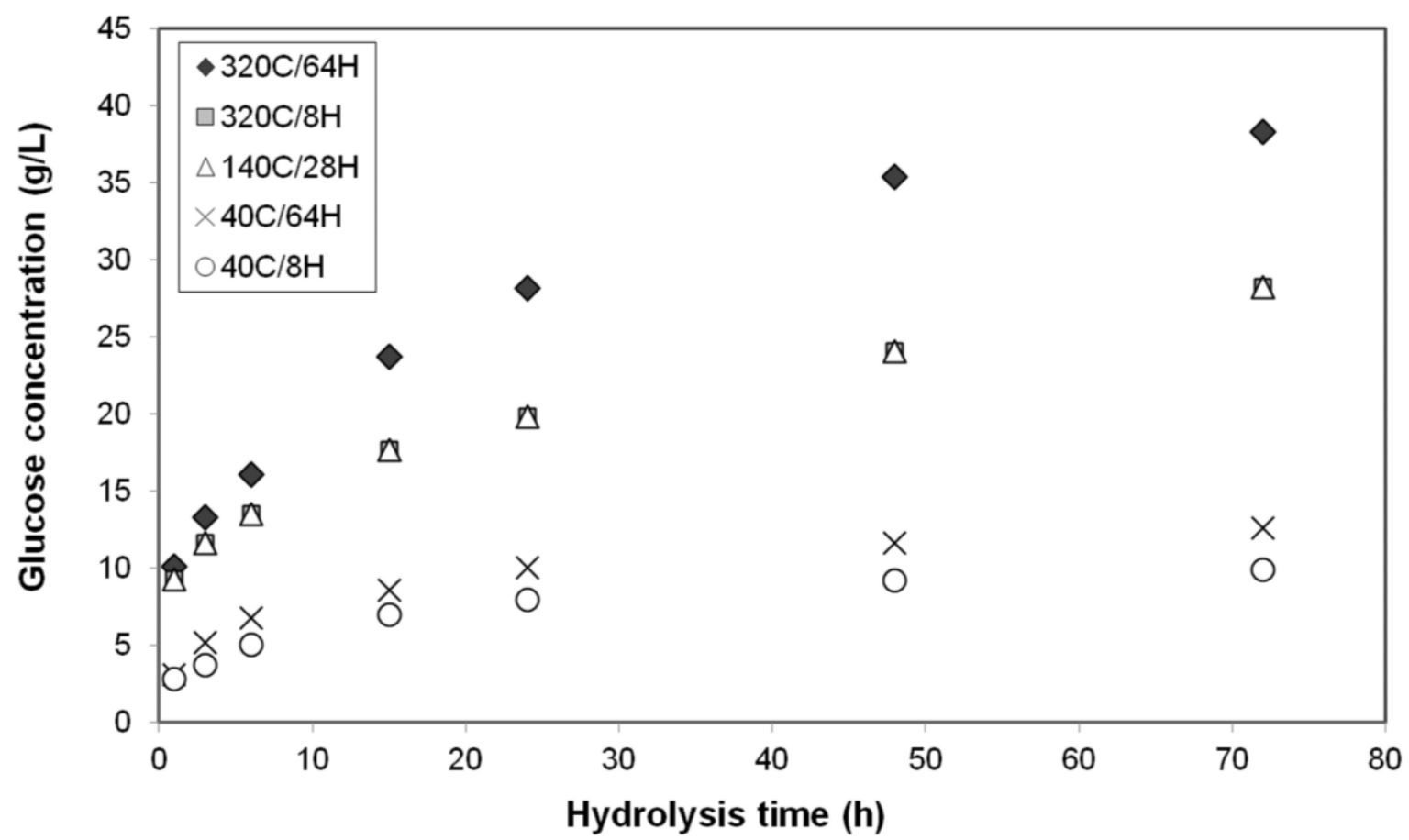

Fig. 4. Concentration of glucose in the liquid phase determined from samples taken 1, 3, $6,15,24,48$, and 72 hours after cellulase addition. N.B 320/64 means that there was $320 \mathrm{~mL}$ of cellulase $/ \mathrm{kg}$ of cellulose and $64 \mathrm{~mL}$ of hemicellulase $/ \mathrm{kg}$ of raw material. $\mathbf{S C}=10 \%, \mathbf{P S}=$ original.

The particle size of the raw material also had a considerable impact on glucose formation. As shown in Fig. 5, the poorest hydrolysis yield was obtained from the fraction composed of the smallest particles (under $125 \mu \mathrm{m}$ ). The fractions containing particles of 125 to $500 \mu \mathrm{m}$ yielded the highest hydrolysate glucose concentration. Reduction of the particle size to submicron scale has been shown, by other workers, to reduce the cellulose crystallinity while simultaneously increasing the specific surface area. Consequently, the yield of glucose has been significantly increased (Yeh et al, 2010). The unexpected results found in this study can perhaps be explained by different cellulose content of the fractions, or by the presence of some compounds capable of disturbing the hydrolysis reaction. It is probable that the content of inorganics, such as carbonates, is highest in the finest fraction, which could explain the inadequate conversion of that fraction. 


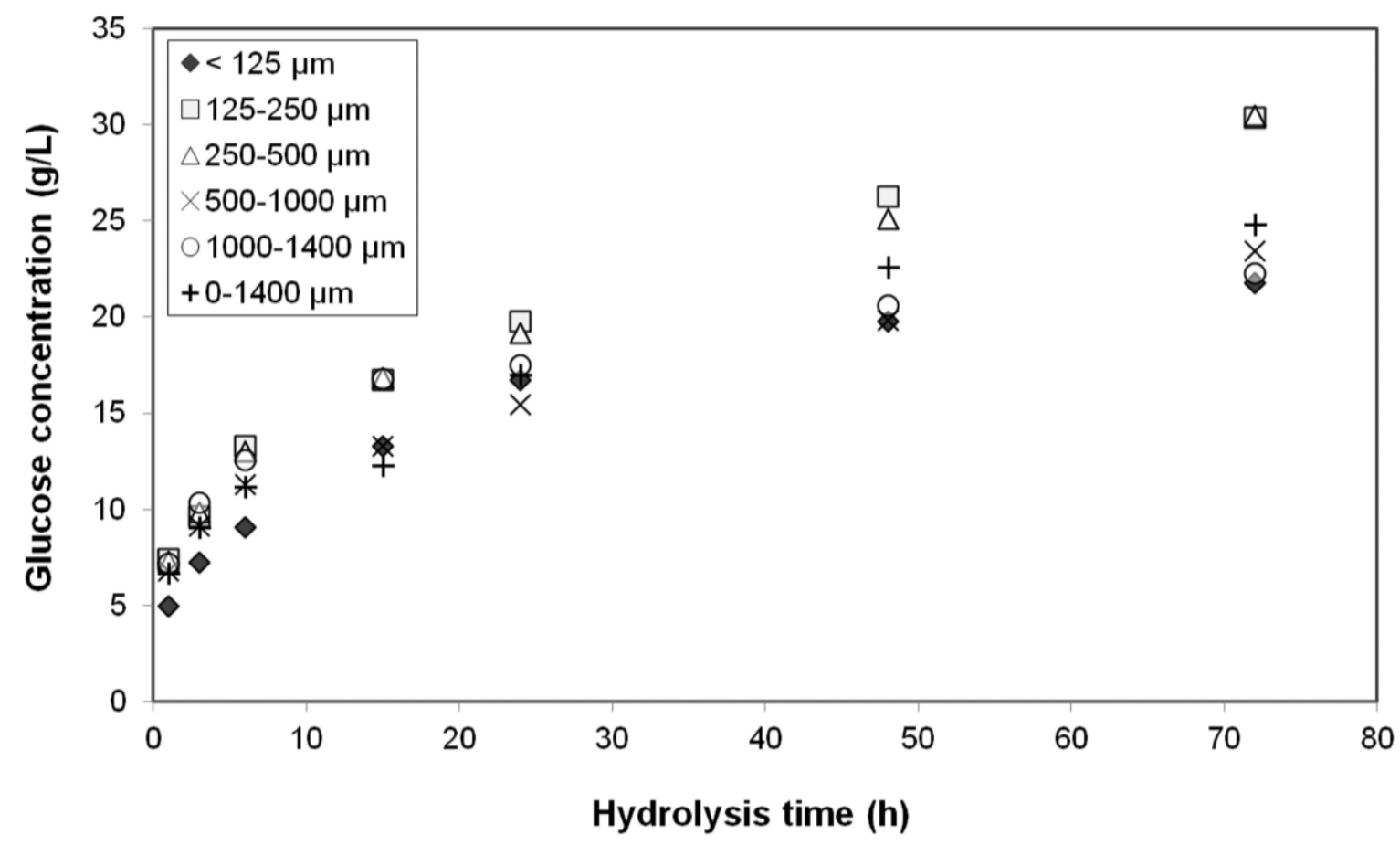

Fig. 5. Concentration of glucose in the liquid phase, determined from samples taken after $1,3,6,15,24,48$, and 72 hours after cellulase addition. Effect of particle size of the raw material. $\mathbf{S C}=10 \%, \mathbf{E D}=140 \mathrm{~mL}$ of cellulase $/ \mathrm{kg}$ cellulose and $28 \mathrm{~mL}$ of hemicellulase / $\mathrm{kg}$ raw material.

The influence of solid concentration of the suspension on the glucose formation during the hydrolysis is presented in Fig. 6. The results were obtained by applying three different solid concentrations, 5, 7.5 and $10 \mathrm{w}-\%$, while keeping the other conditions constant. Glucose concentrations obtained under the above-mentioned conditions in 72 hours were 10, 17, and 29 $\mathrm{g} / \mathrm{L}$, respectively.

Unlike in a typical enzymatic hydrolysis of cellulose, the conversion yield (Fig. 3) was observed to be lower as a result of lower solid concentrations. It can be seen in Fig. 6 that the conversion rate in experiments performed at a SC of 5 and $7.5 \%$ starts to slow down dramatically after 6 hours of hydrolysis. One reason for that could be found in the changing mixing conditions of the suspension. Since the rotation speed of the impeller was constant, $200 \mathrm{rpm}$, the localized velocities throughout the suspension was higher at low solid concentrations.

Excessively intense mixing is generally known to decrease the conversion yield through partial deactivation of enzymes (Ingesson et al., 2001). Therefore, the mixers and rotation speeds for different suspensions should always be chosen with care. However, the effect of mixing type and intensity was not investigated in the present study. 


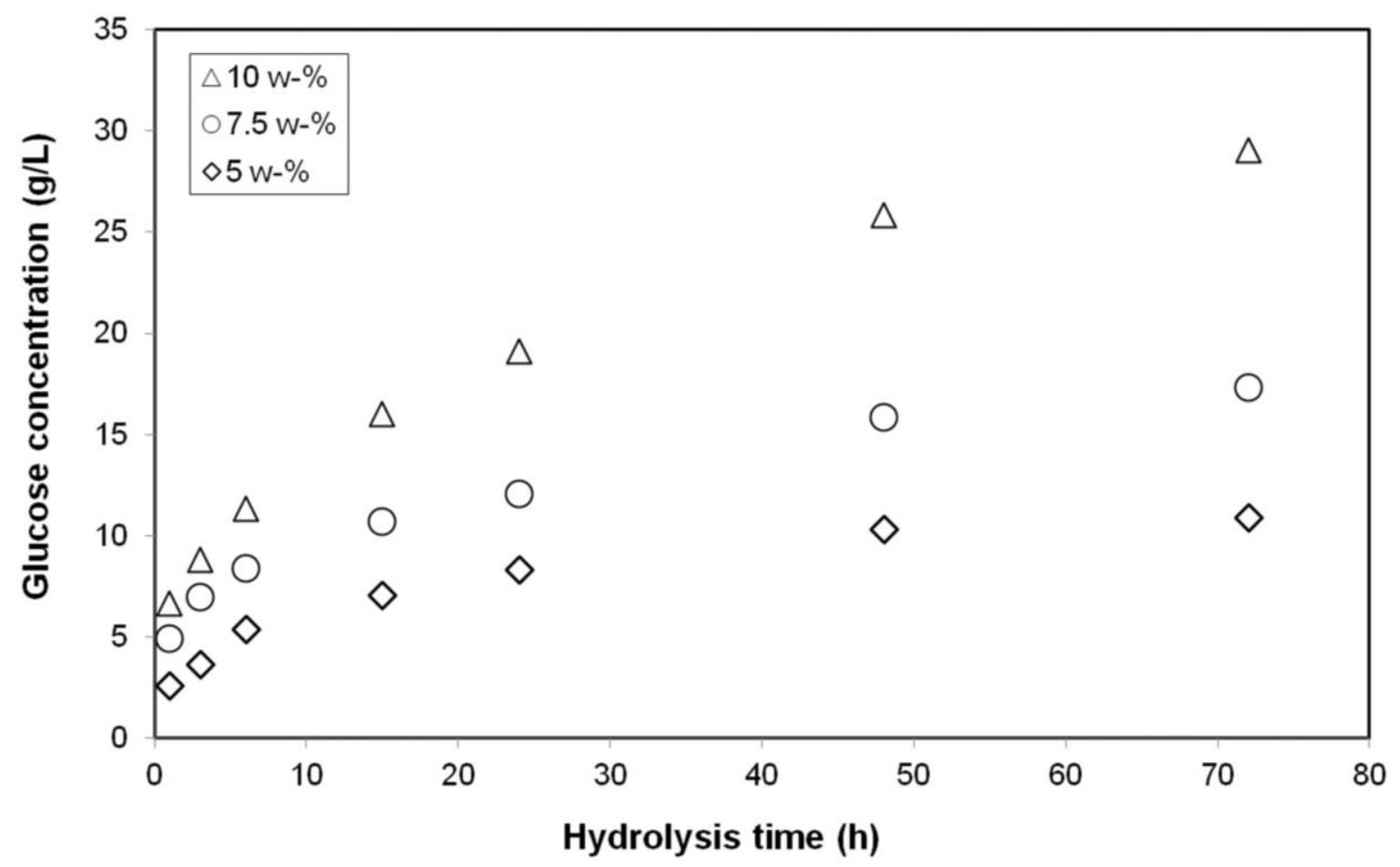

Fig. 6. Concentration of glucose in the liquid phase determined from samples taken after 1, 3, 6, 15, 24, 48, and 72 hours after cellulase addition. PS = original, ED $=140 \mathrm{~mL}$ of cellulase $/ \mathrm{kg}$ cellulose and $28 \mathrm{~mL}$ of hemicellulase $/ \mathrm{kg}$ raw material.

\subsection{Conversion of xylan to xylose}

Xylose is the most common pentose sugar derived from the hemicellulose present in most hardwood species (Balat et al., 2008). The high xylose concentration in the hydrolysates indicated that hardwood species such as birch had been used as one component of the cardboard that was the raw material for the experiments.

Significant concentrations of xylose were detected in the hydrolysates. The relative concentrations of xylose in the experiments were fairly similar to those of glucose (Figs. 3-6). Xylose concentrations amounted to 29 to $46 \%$ of the glucose concentrations determined in the same samples, which implies that it could be economically interesting to utilize xylose in the subsequent ethanol fermentation as well. There are still, however, technical difficulties with the co-fermentation of pentose and hexose sugars. This is why pentose sugars, including xylose, are often removed in the pretreatment stage of the cellulosic raw material.

\subsection{Filtration of hydrolysates}

The filtration experiments were carried out using a laboratory scale Nutsche pressure filter at $1,3.5$ and 6 bar. The filtration temperature was $20^{\circ} \mathrm{C}$ unless otherwise mentioned.

The filterability of the hydrolyzed suspension was markedly better when the enzyme dosage was low, i.e. when a smaller proportion of cellulose had been converted to glucose. This is because a high degree of hydrolysis will shorten the cellulosic fibers (Clarke et al., 2011), thus reducing the characteristic particle size of the solid. The other hydrolysis products, such as sugar oligomers and cellobiose, (as well as liberated lignin) can also have a negative influence on the filtrate flow rate. During a filtration experiment, the fine fibers and lignin may be 
deposited in the filter medium, especially during the initial period when the cake is not yet formed. This means that if the same filter medium is used several times, the accumulated material must be removed at certain intervals. Spray washing at a high pressure is commonly applied in industrial filtration.

The results reveal interesting things about premilling of the raw material. The finest fraction (that passed through the $125 \mu \mathrm{m}$ sieve) was easiest to filter and had the lowest filter cake resistance. The premilled raw material comprising all the fractions (0 to $1.5 \mathrm{~mm})$ exhibited the second lowest specific filter cake resistance. The filterability of the suspensions seems to correlate quite well with the conversion yield of the fractions. The most probable explanation for that is the different composition of the fractions. If the composition of the fractions was identical, smaller particle size would result in an improved conversion yield, which should generally cause difficulties in the filtration stage. In this case, however, the finest fraction is likely to contain relatively large amounts of inorganic fillers like $\mathrm{CaCO}_{3}$, and possibly contain a larger amount of metals and plastic materials as well. Another reason for the good filterability of the finest fraction could be the particle shape.

Determination of ash content (ISO 1762:2001, $525^{\circ} \mathrm{C}$ ) was performed for three fractions to confirm the assumption regarding the presence of inorganic materials in the fractions. The size fractions were 1-1.4 $\mathrm{mm}$ (coarse), 0-1.5 mm (all fractions), and $<0.125 \mathrm{~mm}$ (fine). The results (averages of duplicates) show that the ash content in the finest fraction was almost $30 \%$ higher than that in the $0-1.5 \mathrm{~mm}$ material (see Fig. 1 for the size distribution). Correspondingly, the ash content in the coarse sample was $11 \%$ lower than that in the $0-1.5 \mathrm{~mm}$ material. These results may explain the relatively low specific cake resistance of the finest fraction and also some of the differences in the glucose yield.

The solid content of the hydrolyzed suspension had a marked effect on the filtration rate. While there was a slight difference between the filtration rates for 7.5 and $10 \%$ suspensions, the filtration rate for the $5 \%$ suspension was much higher. In addition to the higher liquid content of the $5 \%$ suspension, the relative quantity of non-converted cellulose in that suspension was largest as well. It is difficult to find a simple explanation for the poor filterability of the $7.5 \%$ hydrolysate, but the heterogeneity of the raw material combined with the influences of mixing might be the major reasons.

One hydrolysis batch was produced to investigate how filtration temperature affects filterability. The applied filtration temperatures were $10,20,30,40$, and $50{ }^{\circ} \mathrm{C}$ and the filtration pressure was 3.5 bar. As expected based on viscosity, the filtration resistance was highest at 10 ${ }^{\circ} \mathrm{C}$ and lowest at $50{ }^{\circ} \mathrm{C}$ (Fig. 7). Filterability at $40{ }^{\circ} \mathrm{C}$ was almost as good as at $50{ }^{\circ} \mathrm{C}$, because the structure of the filter cake started to change, i.e. the cake started to collapse at $50{ }^{\circ} \mathrm{C}$. The cake thicknesses after filtration at 10,40 and $50{ }^{\circ} \mathrm{C}$ were $27.4,25.1 \mathrm{~mm}$ and $23.1 \mathrm{~mm}$, respectively. The average porosity of the filter cake formed at $50{ }^{\circ} \mathrm{C}$ was therefore reduced in comparison with the cakes formed at lower filtration temperatures. It is apparent that the cake collapse plays an important role in the process as the temperature is increased, but it is unclear if the filterability could be much improved by heating the suspension closer to $100{ }^{\circ} \mathrm{C}$. Moreover, heating can cause degradation of the fermentable sugars and would inevitably increase the energy consumption of the process. 


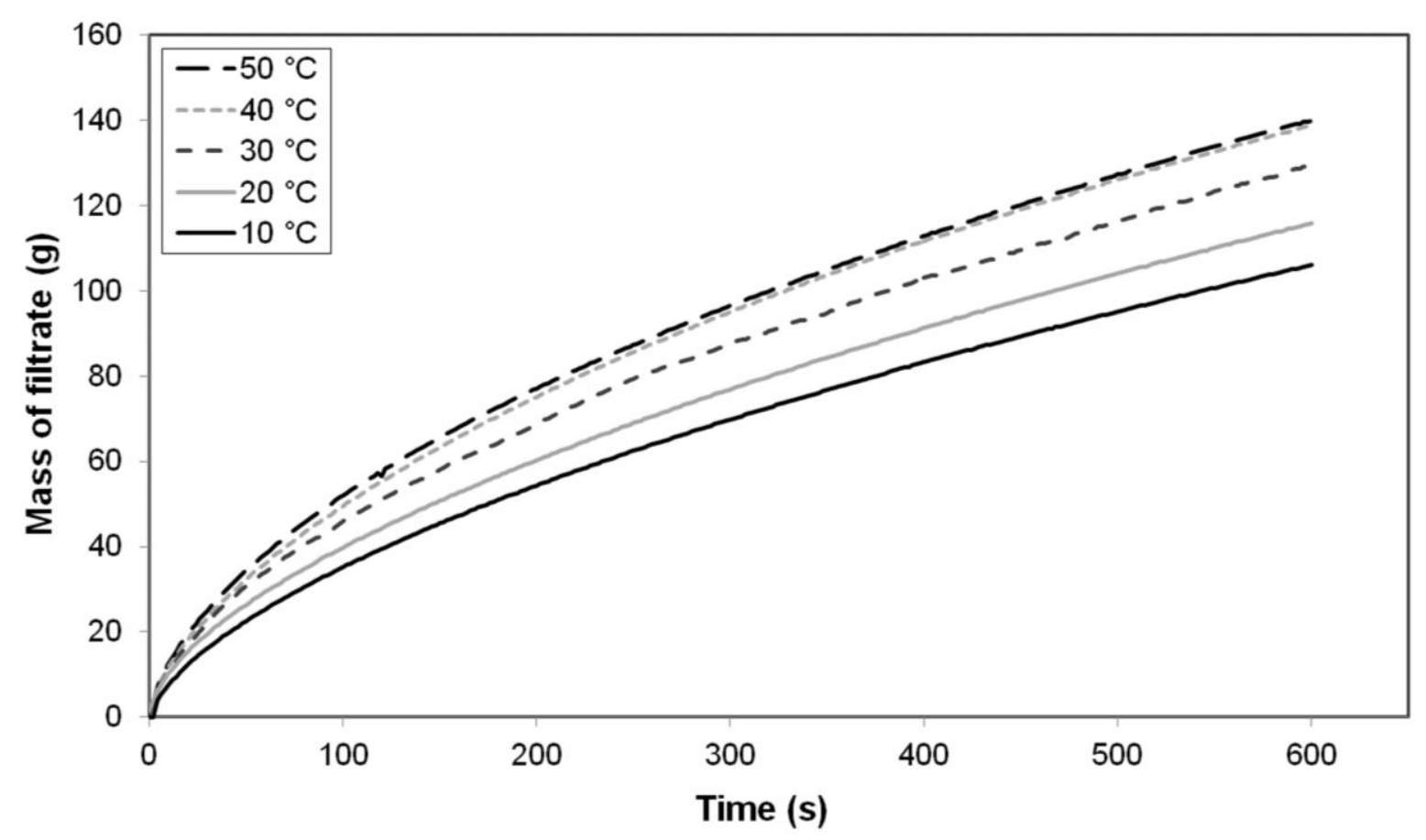

Fig. 7. Effect of filtration temperature on pressure filtration at $\Delta \mathrm{p}=3.5$ bar. $\mathbf{E D}=140$ $\mathrm{mL}$ of cellulase $/ \mathrm{kg}$ cellulose and $28 \mathrm{~mL}$ of hemicellulase $/ \mathrm{kg}$ raw material, PS $=$ original, $\mathbf{S C}=10 \%$.

The results presented in Fig. 7 do not differ from each other as much as could have been expected, based on charnge in viscosity of the filtrate. Based on laboratory measurements done by using a capillary viscosimeter, the viscosity of solid-free hydrolysate is only slightly higher than that of water. Although the viscosity of water decreases by almost $60 \%$ as the temperature is increased from 10 to $50{ }^{\circ} \mathrm{C}$, the observed improvement in the average flow rate of the filtrate is smaller, $33 \%$. The main reason for this is the exceptionally high compressibility of the filter cakes at $50{ }^{\circ} \mathrm{C}$.

\subsection{Filter cake characteristics}

The average resistances of the filter cakes obtained at filtration pressures of 1, 3.5, and 6 bar are presented in Figs. 9-11. Mainly because of the high compressibility of the hydrolyzed solid residue, the specific cake resistances were high, ranging from $1.2 \cdot 10^{11} \mathrm{~m} / \mathrm{kg}$ to $3.8 \cdot 10^{12} \mathrm{~m} / \mathrm{kg}$. The fibrous structure of the cardboard waste and the filter cakes can be seen in Fig. 8. The difference in the color of the raw material and the solid residual is caused by lignin that is not significantly dissolved or degraded in the hydrolysis. Therefore, as cellulose is converted to glucose, the proportion of lignin in the solid fraction is increased. The physicohemical properties of lignin (adsorptivity on cellulose, hydrophobicity, low water permeability, etc.) cause high filtration resistances. Based on the experimental results, this applied in the present study as well. The challenging separation of lignin from hydrolysates has been earlier studied by Johansson (2005). As shown in Fig. 8B, there are still fibers that have not been converted to glucose. Pretreatment of the raw material would help to hydrolyze this part better. 


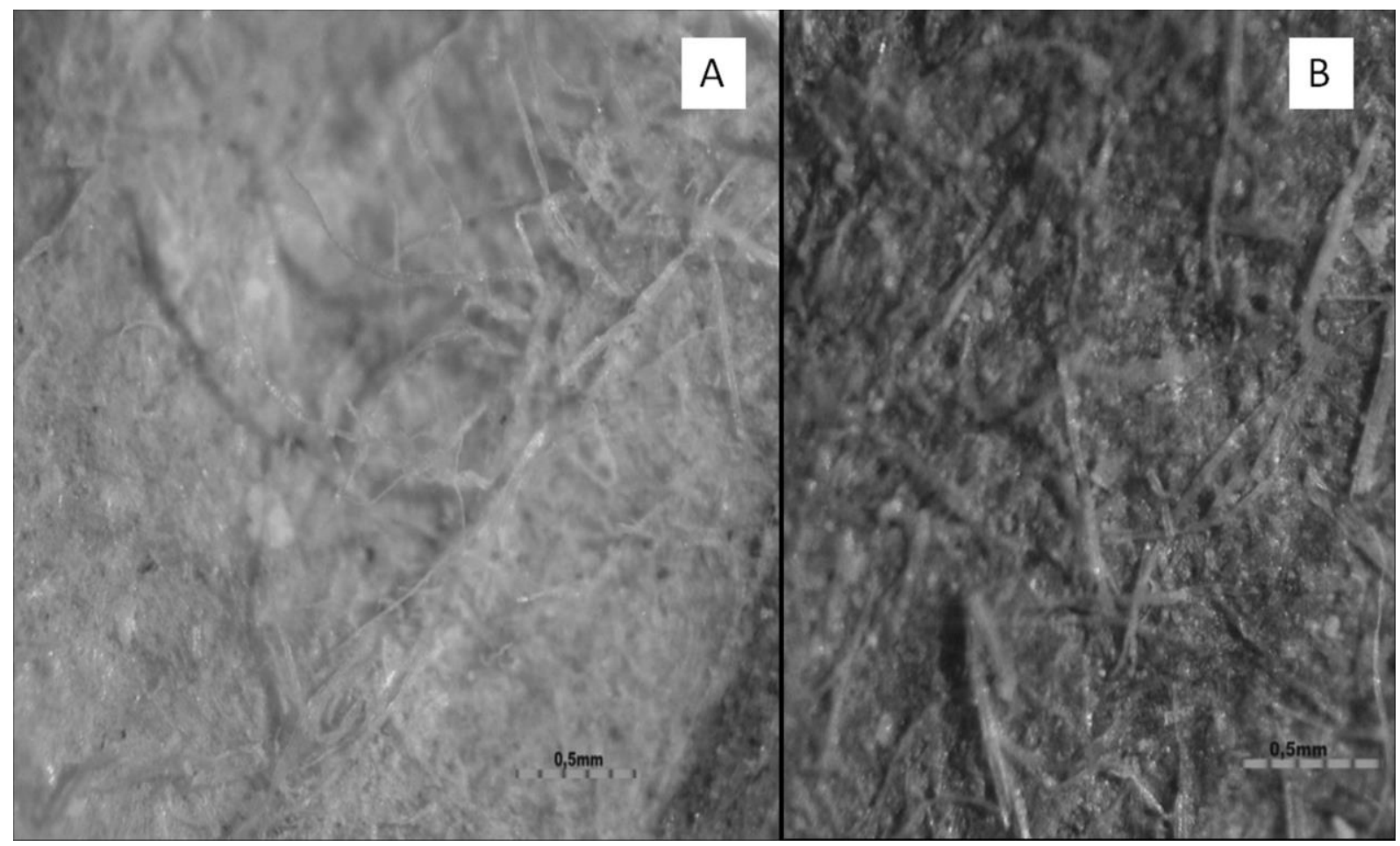

Fig. 8. Stereomicroscope photos $(100 \mathrm{x})$ of the raw material (A) and the filter cake of test 1 (B).

Figure 9 shows the average specific cake resistances, obtained at different enzyme dosages. The resistances of the filter cakes obtained at the highest enzyme dosage $\left(320 \mathrm{~mL}_{\text {cellulase }} / \mathrm{kg}_{\text {cellulose }}\right.$ and $64 \mathrm{~mL}$ hemicellulase $/ \mathrm{kg}_{\text {raw material }}$ ) were clearly the highest. Unfortunately, the conversion yields were highest when filtration was most difficult. The specific cake resistances increased significantly during the hydrolysis; after the $\mathrm{pH}$ adjustment, at zero conversion, at 1 bar, the average specific cake resistance was $2 \cdot 10^{10} \mathrm{~m} / \mathrm{kg}$. The filterability of well-hydrolyzed suspensions could be perhaps improved, for instance, by using flocculants, such as commercial polyelectrolytes, or filter aids, such as sawdust. The overall sugar yields could be further increased by cake washing. In industrial filters, high filtration capacities and sugar yields are required, so the use of filter aids and cake washing should always be considered. 


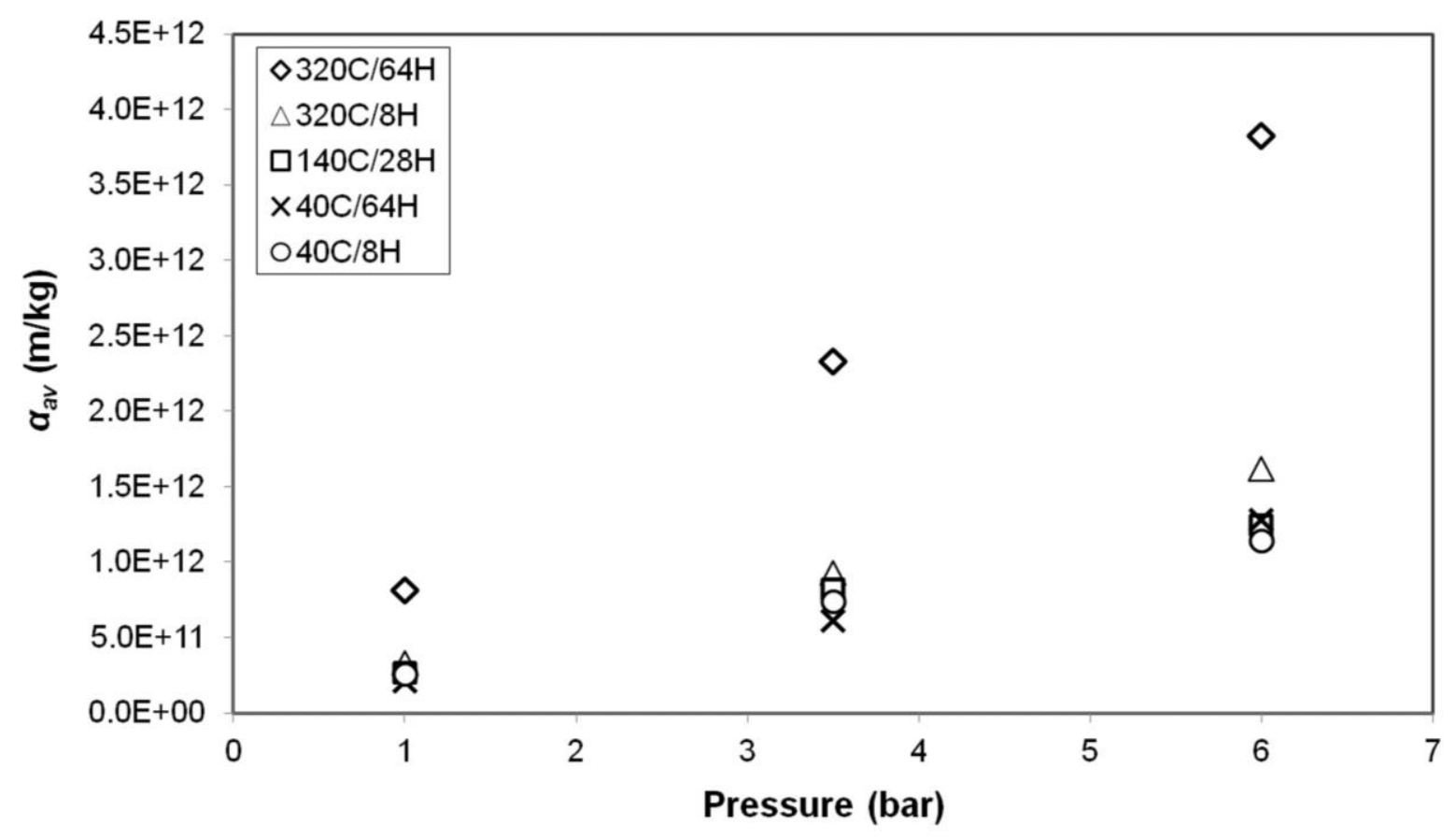

Fig. 9. Effect of enzyme dosage on average resistances of filter cakes at filtration pressures of 1, 3.5, and 6 bar. $\mathbf{P S}=$ original, $\mathbf{S C}=10 \%$.

The medium resistances $R_{m}$ were practically negligible in comparison with the cake resistances $R_{c}$ calculated from Eq. (3). This is a typical case in cake filtration processes. A fresh piece of high-quality filter medium was used for each test, so the initial properties of the filter media were comparable between the tests. In the experimental determination of $R_{m}$, the approximated values of $R_{m}$ increased with the filtration pressure, ranging from $2 \cdot 10^{11} 1 / \mathrm{m}$ at 1 bar to $6 \cdot 10^{11}$ $1 / \mathrm{m}$ at 6 bar. $R_{m}$ also correlated with the yield, which implies that the fines may cause partial clogging of the filter medium. Lignin is likely to have an important role in this phenomenon. The effect of the initial raw material particle size on the average specific resistance of the filter cake is shown in Fig. 10. The finest fraction containing particles passing through $125 \mu \mathrm{m}$ sieve can be seen to produce the lowest specific cake resistance at all applied pressure differences. The differences in the filtration behavior are likely to be caused by the differences in the composition and characteristics of the size fractions. 


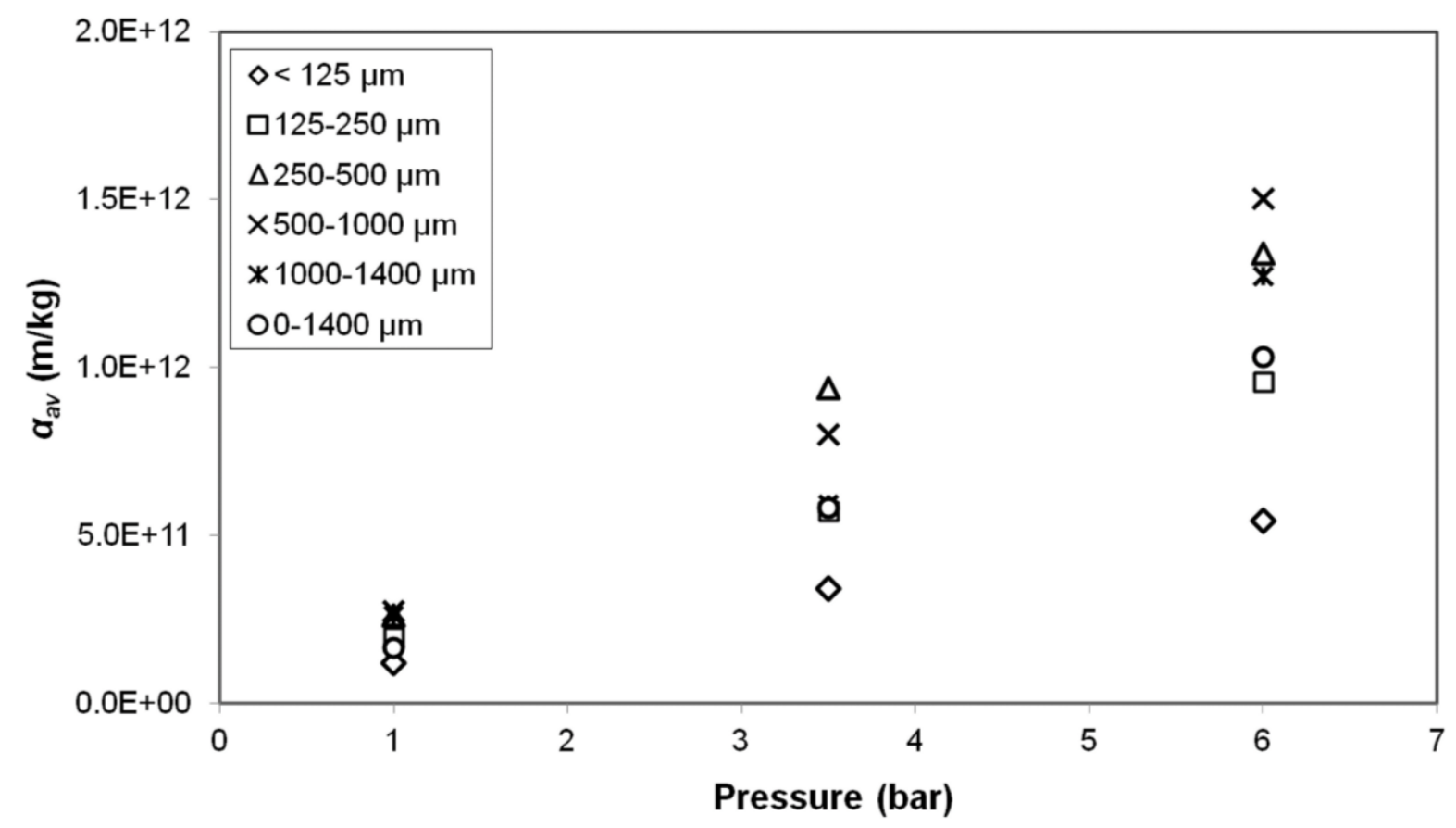

Fig. 10. Effect of particle size of the raw material on average resistances of filter cakes at filtration pressures of 1, 3.5, and 6 bar. $\mathbf{E D}=140 \mathrm{~mL}$ of cellulase $/ \mathrm{kg}$ cellulose and $28 \mathrm{~mL}$ of hemicellulase $/ \mathrm{kg}$ raw material, $\mathbf{S C}=10 \%$.

Compared to the original, non-milled raw material (Fig. 9, 140C/28H), the specific cake resistances (Fig. 10) were generally lower. The specific cake resistances of the milled raw material $(0-1400 \mu \mathrm{m})$ at filtration pressures of 1, 3.5, and 6 bar were 41, 29, and $17 \%$ lower, respectively, than those of the original material. For some reason, the conversion yield of the milled raw material was about $15 \%$ lower.

Fig. 11 shows the influence of solid concentration on the average resistance of the filter cakes. The highest specific cake resistances were found for the suspension containing $7.5 \%$ solids. Especially in experiments where the pressure difference was 3.5 and 6 bar, specific cake resistances for the $7.5 \%$ suspension were high. The compressibility index for the $7.5 \%$ suspension was over 1.0, which means (am Ende, 2010; Oja, 1996) that the filtered suspension can be regarded as highly compressible. 


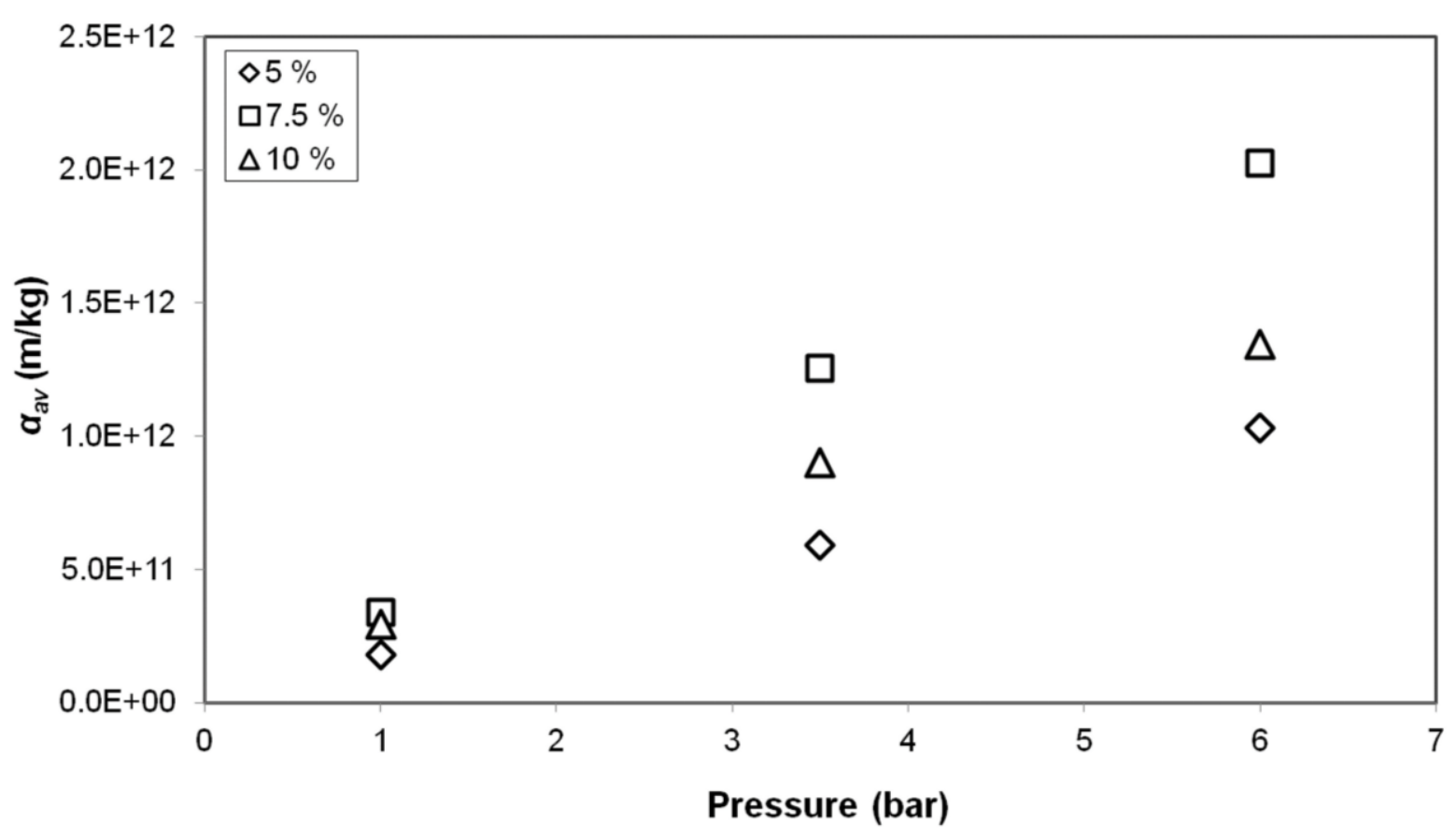

Fig. 11. Effect of solid concentration of the suspension on average resistances of filter cakes at filtration pressures of 1, 3.5, and 6 bar. $\mathbf{E D}=140 \mathrm{~mL}$ of cellulase $/ \mathrm{kg}$ cellulose and $28 \mathrm{~mL}$ of hemicellulase $/ \mathrm{kg}$ raw material, $\mathbf{P S}=$ original.

There was a large difference between the lowest and highest specific cake resistance: the lowest value, $1.8 \cdot 10^{11} \mathrm{~m} / \mathrm{kg}$, was obtained for $5 \%$ suspension at 1 bar, whereas the highest value, $2.0 \cdot 10^{12} \mathrm{~m} / \mathrm{kg}$, was obtained for $7.5 \%$ suspension at 6 bar. As discussed earlier, mixing conditions and the heterogeneity of the raw material are probable factors behind these peculiar results.

\subsection{Porosity and compressibility of the filter cakes}

The average porosity of the filter cakes, i.e. the volume fraction of pores in the cake, depended on the conversion yield as presented in Fig. 12. Generally, higher conversion yields correlated with reduced porosity of the filter cakes. Enzyme dosage had the largest impact on the conversion yield and thus on the average porosity. Consequently, the two experimental batches in which the enzyme dosages were the lowest, have the highest porosities (0.73 to 0.78 ) and are separately located on the left hand side of the chart in Fig. 12. The highest conversion yield ( 0.55$)$ obtained at the highest enzyme dosage was probably the main reason for the lowest porosities (0.69 to 0.70$)$ of these filter cakes. 


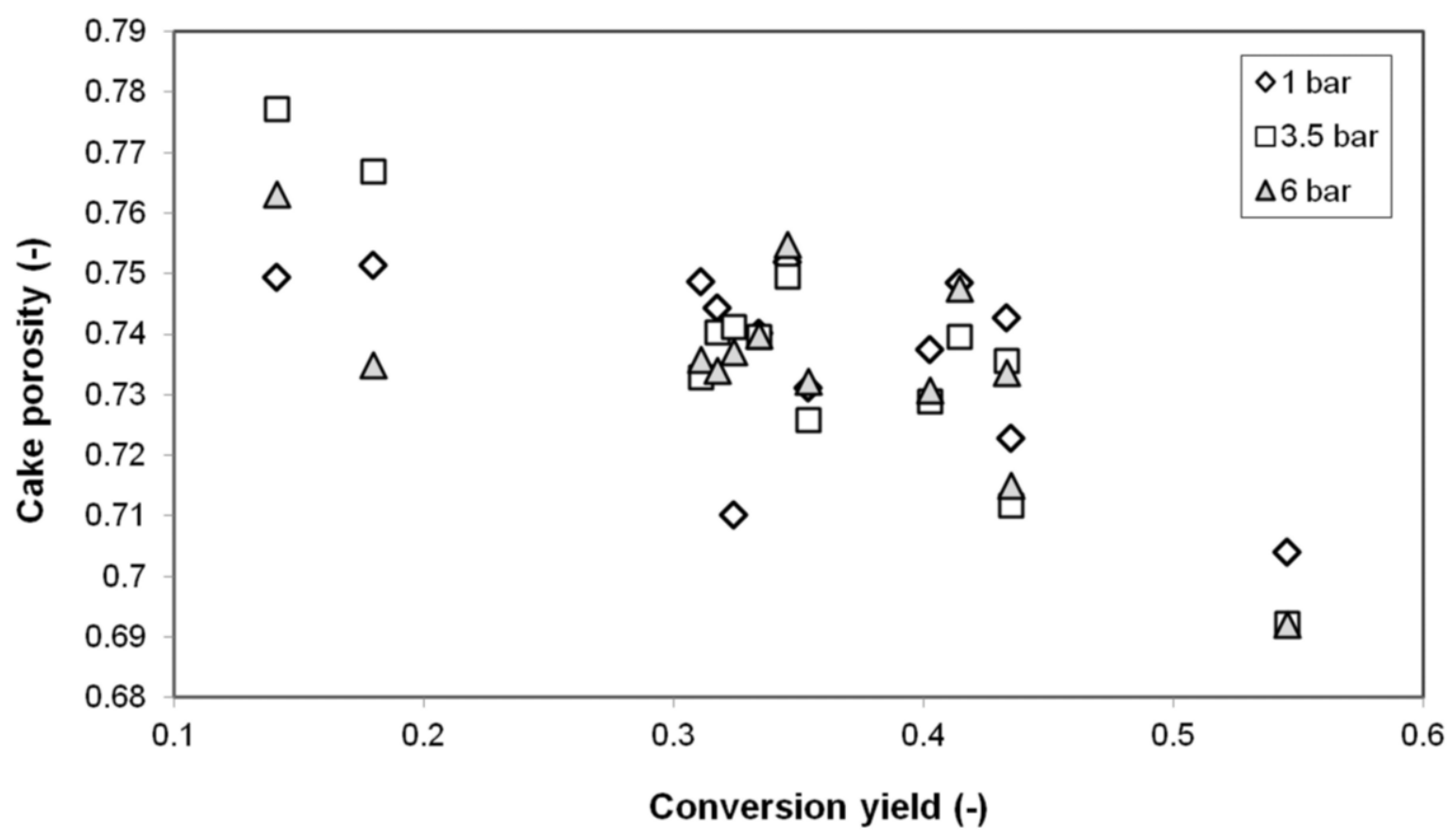

Fig. 12. Cake porosity versus conversion yield. Pressure difference $=1.0,3.5$, and 6.0 bar.

The conversion yield did not have such a clear correlation with the compressibility index $n$. The measured compressibility indices (Table 3 ) varied from 0.82 to 1.03 , indicating that the cakes were either compressible or highly compressible. While the suspension produced using the lowest enzyme dosage (Test 14) had the lowest compressibility index $(n=0.82)$, the suspension produced from the milled raw material (Test 8) was the most compressible, $n=1.03$.

Table 3 Compressibility indices, $n$, obtained as a result of various hydrolysis conditions.

\begin{tabular}{|c|c|c|c|c|c|c|}
\hline \multirow{2}{*}{$\begin{array}{l}\text { Experimen } \\
t\end{array}$} & \multicolumn{3}{|c|}{ Enzyme dosage } & \multirow{2}{*}{$\begin{array}{c}\text { Solid concentration } \\
{[\mathrm{w}-\%]}\end{array}$} & \multirow{2}{*}{$\begin{array}{c}\text { Particle size } \\
{[\mu \mathrm{m}]}\end{array}$} & \multirow{2}{*}{$\begin{array}{c}n \\
{[-]}\end{array}$} \\
\hline & $\begin{array}{c}\text { C-Tec } \\
{[\mathrm{mL} / \mathrm{kg} \text { cellulose] }}\end{array}$ & $\begin{array}{c}\text { C-Tec } \\
\text { [FPU/g cellulose] } \\
\end{array}$ & $\begin{array}{c}\text { H-Tec } \\
{[\mathrm{mL} / \mathrm{kg} \text { substrate] }} \\
\end{array}$ & & & \\
\hline 1 & 320 & 38.4 & 64 & 10 & original & 0.86 \\
\hline 2 & 140 & 16.8 & 28 & 10 & original & 0.85 \\
\hline 3 & 140 & 16.8 & 28 & 10 & $<125$ & 0.84 \\
\hline 4 & 140 & 16.8 & 28 & 10 & $125-250$ & 0.88 \\
\hline 5 & 140 & 16.8 & 28 & 10 & $250-500$ & 0.94 \\
\hline 6 & 140 & 16.8 & 28 & 10 & $500-1000$ & 0.94 \\
\hline 7 & 140 & 16.8 & 28 & 10 & $1000-1400$ & 0.84 \\
\hline 8 & 140 & 16.8 & 28 & 10 & $0-1400$ & 1.03 \\
\hline 9 & 140 & 16.8 & 28 & 5 & original & 0.97 \\
\hline 10 & 140 & 16.8 & 28 & 7.5 & original & 1.01 \\
\hline 12 & 320 & 38.4 & 8 & 10 & original & 0.87 \\
\hline 13 & 40 & 4.8 & 64 & 10 & original & 0.97 \\
\hline 14 & 40 & 4.8 & 8 & 10 & original & 0.82 \\
\hline
\end{tabular}




\subsection{Repeatability of the experiments}

Since each filtration test was carried out twice, it was possible to evaluate the repeatability of the experiments. The repeatability was evaluated based on the average volumetric flow rate of the filtrate during each test. Average flow rate of the parallel tests was calculated and the relative differences $(\%)$ from the average were used for repeatability evaluation. Generally, the differences were small, 1 to $2 \%$ from the mean flow rates.

\section{Conclusions}

The objective of this experimental study was to investigate how the solid-liquid separation of hydrolysates produced by enzymatic hydrolysis from cardboard waste is influenced by the enzyme dosage, premilling of the raw material, solid concentration, and temperature of filtration.

The degree of conversion of the cellulosic raw material to simple sugars (glucose and xylose) was influenced by a number of factors. The raw material was observed to be very heterogeneous, which may have caused uncertainty about the accuracy of the results. Enzyme dosage had the biggest impact on the conversion yield, but the economy of the process places limits on the use of enzymes in industrial applications. Quite surprisingly, premilling of the raw material did not increase the conversion yield and did not have a significant effect on the hydrolysis kinetics. Different amounts of sugars were produced from the separated size fractions of the premilled raw material, which implies that the material composition of the fractions was not exactly uniform. Conversion of cellulose to glucose was most efficient at the highest solid concentration of $10 \%$. The typical concentration of xylose in the hydrolysates was approximately $30 \%$ of the corresponding glucose concentration. It is apparent that proper pretreatment of the raw material and operation at higher solid concentrations would be required to make the process economically feasible.

A low conversion yield, as a result of low enzyme dosage, corresponded with improved filterability of the hydrolysate. A high conversion yield, on the contrary, was the most important factor causing poor filterability. Unlike in mineral engineering applications, the smallest size fraction was, surprisingly, the easiest one to filter. The reason for that may be the composition of the fraction, i.e. a higher ash content and therefore a lower conversion yield and a relatively low compressibility of the cake.

Differences in particle shape and composition of the size fractions were not analyzed in this study, but these factors are likely to have a very important role in the filtration process. Filtration rate was higher at lower solid concentration of the suspension, possibly because of lower conversion yield. In industrial applications, however, the solid concentrations would need to be significantly higher than the concentrations used in this study. The average resistance of the filter cake was exceptionally high in case of the $7.5 \%$ suspension. Increasing the filtration temperature from 10 to $40{ }^{\circ} \mathrm{C}$ resulted in moderately improved filtration rates, but the filter cakes become more compressible. Filtration at $40{ }^{\circ} \mathrm{C}$ was almost as easy as at $50{ }^{\circ} \mathrm{C}$, which indicates that the optimum filtration temperature, taking into account the economy and the filter performance, might be about $50{ }^{\circ} \mathrm{C}$. Fortunately, the enzymatic hydrolysis is optimally 
performed at the same temperature. The structure of the filter cake can change dramatically, the cake can collapse at higher temperatures.

Average specific resistances of the filter cakes were high, $1.2 \cdot 10^{11} \mathrm{~m} / \mathrm{kg}$ to $3.8 \cdot 10^{12} \mathrm{~m} / \mathrm{kg}$. High enzyme dosage was the main factor for increased specific cake resistances. Porosities of the cakes ranged from 0.69 to 0.78 . High porosities were obtained together with poor conversion yield. The cakes were either compressible or highly compressible: the compressibility indices varied from 0.82 to 1.03 , but did not clearly correlate with the conversion yield.

The results obtained in this study can be applied in pressure filtration operations when the slurry is of a similar type, i.e. processed cellulose, such as paper, cardboard or pulp. Especially the enzyme dosage and the filtration temperature are likely to have similar effects on filtration of other biomass slurries. The results are not directly applicable to hydrolysates containing higher proportions of lignin. Additionally, pretreatment of the raw material has also an influence on the enzymatic conversion and the subsequent filtration.

\section{References}

Alvira, P., Negro, M.J., Ballesteros, M., 2011. Effect of endoxylanase and $\alpha$-Larabinofuranosidase supplementation on the enzymatic hydrolysis of steam exploded wheat straw. Bioresource Technol, 102, 4552-4558.

Balat, M., Balat, H., Öz, C., 2008. Progress in bioethanol processing. Prog Ener Combust, 34, 551-573.

Blasi, C.D., Signorelli, G., Russo, C., Rea, G., 1999. Product distribution from pyrolysis of wood and agricultural residues. Ind Eng Chem Res, 38(6), 2216-2224.

Black, H.C.Jr., 1951. Determination of sodium carboxymethylcellulose in detergent mixtures by the anthrone method. Anal Chem, 23, 1792-1795.

Burke, D.R., Anderson, J., Gilcrease, P.C., Menkhaus, T.J., 2011. Enhanced solid-liquid clarification of lignocellulosic slurries using polyelectrolyte flocculating agents. Biomass Bioenerg 35, pp. 391-401.

Clarke, K., Li, X., Li, K., 2011. The mechanism of fiber cutting during enzymatic hydrolysis of wood biomass. Biomass Bioenerg, 35, 3943-3950.

am Ende, D.J., 2010. Chemical engineering in the pharmaceutical industry: R\&D to manufacturing. John Wiley \& Sons.

Ingesson, H., Zacchi, G., Yang, B., Esteghlalian, A.R., Saddler, J.N., 2001. The effect of shaking regime on the rate and extent of enzymatic hydrolysis. J Biotechnol, 88, 177-182.

Johansson, C., 2005. Pressure and solidosity profiles in cake filtration. Ph.D. Thesis. Chalmers University of Technology, Gothenburg, Sweden.

Kochergin, V., Miller, K., 2011. Evaluation of target efficiencies for solid-liquid separation steps in biofuels production. Appl Biochem Biotechnol, 163, 90-101.

Krässing, HA., 1993. Effect of structure and morphology on accessibility and reactivity. Cellulose: structure, accessibility, and reactivity. Gordon and Breach Science Publishers, 11, 167-324. 
Kumar, P., Barrett, D., Delwiche, M.J., Stroeve, P., 2009. Methods for pretreatment of lignocellulosic biomass for efficient hydrolysis and biofuel production. Ind Eng Chem Res, 48, 3713-3729.

Lin, Y., Tanaka, S., 2006. Ethanol fermentation from biomass resources: current state and prospects. Appl Microbiol Biotechnol, 69, 627-642.

Lin, L., Yan, R., Liu, Y., Jiang, W., 2010. In-depth investigation of enzymatic hydrolysis of biomass wastes based on three major components: cellulose, hemicellulose and lignin. Bioresource Technol, 101, 8217-8223.

Mansfield, S.D., Mooney, C.M., Saddler, J., 1999. Substrate and enzyme characteristics that limit cellulose hydrolysis. Biotechnol prog, 15, 804-816.

Oja, M., 1996. Pressure filtration of mineral slurries: Modelling and particle shape characterization. Doctoral Thesis. Lappeenranta University of Technology, Lappeenranta, Finland.

Sluiter, J.B., Rutz, R.O., Scarlata, C.J., Sluiter, A.D., Templeton, D.W., 2010. Compositional analysis of lignocellulosic feedstocks. 1. Review and description of methods. J Agric Food Chem, 58, 9043-9053.

Svarovsky, L. (1981). Solid-liquid separation, second ed. Butterworth \& Co, Witham, Essex.

Wakeman, R.J., Tarleton, E.S., 1999. Filtration Equipment selection, modelling and process simulation. Elsevier Science Ltd, Kidlington, Oxford.

Wingren, A., Galbe, M., Zacchi, G., 2008. Energy considerations for a SSF-based softwood ethanol plant. Bioresource Technol, 99, 2121-2131.

Virkajärvi, I., Veringa Niemelä, M., Hasanen, A., Teir, A., 2009. Cellulosic ethanol via biochemical processing poses a challenge for developers and implementers. Bioresources, 4(4), $1718-1735$.

Yáñez, R., Alonso, J.L., Parajó, J.C., 2004. Production of hemicellulosic sugars and glucose from residual corrugated cardboard. Process Biochem, 39, 1543-1551.

Yeh, A.-I., Huang, Y.-C., Chen, S.H., 2010. Effect of particle size on the rate of enzymatic hydrolysis of cellulose. Carbohyd Polym, 79, 192-199. 